Review Article

\title{
The Fragrant Joom revisited: A translation of Kokborok poetry in English by Ashes Gupta
}

\author{
Ashes Gupta, The Fragrant Joom revisited: A translation of Kokborok poetry in English \\ (Akshar Publications, Agartala 2017), 144 pages, Rs. 250.
}

Reviewed by Sukla Singha

Research Scholar, Department of English, Tripura University, Tripura, India.

Orcid: oooo-0oo3-4948-7297.Email: shukla.singha85@gmail.com

When one wishes to read and understand a piece of literary writing (poem or prose) originally written in a language very different from one's own and probably even beyond one's comprehension, one is left with no other choice but to depend on the translation of the original text, in a language that one is familiar with, although not necessarily one's mother tongue. The text in question is The Fragrant Joom revisited, a collection of poems originally written in Kokborok, the principal language of the natives of the state of Tripura, and translated to English by Ashes Gupta, eminent translator and academician of the state. The first edition of the book had come out in 2006, and in the words of the translator and editor:

"A decade has passed since the first publication of The Fragrant Joom in 2006. It's time to revisit the old joom again, time to feel new blooms and new fragrances that time had brought to life in a land criss-crossed by myriad influences - social, economic, cultural and political."

In the foreword to the second edition, Gupta bares all his heart and words describing why he started taking a keen interest in Kokborok poetry despite belonging to a different community (Bengali) of the state. He calls himself "an involved outsider and not an involved insider" whose refugee ancestors, when they were disowned by their own homeland (Bangladesh), had found shelter and solace in this land inhabited by indigenous people. Through this anthology, Gupta expresses his gratitude to the poets and the people of Tripura who encouraged him in this literary odyssey that he feels is an "acknowledgement of that debt, which many of my own people, disoriented as they are, have forgotten to acknowledge." He further adds that the vogue of translating Kokborok poetry does not claim of an age old history and is born out of his growing interest in the tribal culture \& literature of the state.

Since I myself do not understand Kokborok, the first thing that had struck me about the volume was perhaps the 'feel-good' title of the book. The word 'Joom' (also written as Jhum) refers to shifting cultivation practiced by the tribal population of Tripura. The native Jhumias (people engaged in shifting cultivation) of Tripura, often referred to as the sons of the soil, share and nurture a deep filial bond with the mysterious dense green forests, the ever beckoning hills, the melancholy tunes of the 'Sumui' and most importantly with the fragrant earth that feeds them. Therefore, the title of the book is aptly suggestive of the emotions of the hill people and their native imagery which run riot throughout the book. This 'revisited' anthology which runs to a

(c) AesthetixMS 2016. This Open Access article is published under a Creative Commons Attribution Non-Commercial 4.0 International License (http://creativecommons.org/licenses/by-nc/4.o/), which permits non-commercial re-use, distribution, and reproduction in any medium, provided the original work is properly cited. For citation use the DOI. For commercial re-use, please contact editor@rupkatha.com. 
total of one hundred and forty-four pages includes the poetry (written mostly in free/ blank verse) of nineteen eminent poets of the state who write in Kokborok. Many of these poets such as Chandrakanta Murasingh, Nandakumar Debbarma, Shefali Debbarma, Bijoy Debbarma etc. have been published in important anthologies on north-east writings published by NEHU (2003), Penguin Books (2009) and Oxford University Press (2011). What is interesting to note is the overarching presence of nature in the works of most of these Kokborok poets. Other prominent themes of their poetry include: romantic love, problems of insurgency in the state, loss of cultural values, loss of identity due to intrusion of dominant groups etc. to name a few.

Shyamlal Debbarma's poem "Reality" takes the reader to the world of the industrious Jhumias who live a hand-to-mouth life in the remote villages, far from the luxuries of the modern city life. In conversation with his elder brother (who seems to be living in the city), the angst of the younger sibling Hachukrai, a jhumia, is expressed in the lines: "I am fine Ata, /gnashing my teeth like all others, /squeezing the last drop of oil /from a single mustard seed, /avoiding demands made by the wife, /with all my children /Surviving Ata /piling debt upon debt (20).

Nature announces her indispensable presence in Kokborok poets. Forests are considered to be the lifeline of the tribal life in Tripura. Hence Nandakumar Debbarma speaks of the emotional relationship between the forests and the indigenous folk of the land: "You cannot abandon her/ She is embedded in your heart. /Neither consumed by fire, /nor destroyed by water/ waking up in your dreams/she speaks to you" (31). In the poem titled "Rain after drought", the poet speaks of a refreshing rain that God had sent on earth for the hardworking jhumias: "Both wearing loincloths /reaching up to the knee, /hesitant faces, /with the fragrance of the earth and corn /all over their body" (29). Sachlang Tripura observes in "In close proximity to people": White bata flowers bloom /in the Longtorai Valley. /Along with it blooms the toksa yadobsa. /The cry of the kungkok bird and / the rambling of rain laden clouds/ spread pollens of love" (100). The rich imagery of the mythical birds 'Uang', 'Nuyai' and the demon 'Asikolok' in the poems of Shyamlal Debbarma, Sudhanya Tripura, Kishore Murasingh and Dipali Debbarma successfully transport the readers to the world of dark folklores and myths that still serve as sentinels to the age-old tribal culture and society of the state: "Asikolokma goes round my home /with steps resounding thum thom thum thom /In whose house is it now.../That scary voice of yours /still raises goose pimples all over my body (21).

The translations of the 'modernist poets', especially the poetry of Bikash Roy Debbarma and Kishore Murasingh make one come to terms with the harsh and painful truth of the never ending conflict between the indigenous folks and the Bengalis (non-tribal population) of the state. Veteran poet Utpal Debbarma's quest for identity in his own homeland is profound in the lines: "On a temporal road I move today /without any constancy in life. /My hearth is dark, companionless I have nowhere to go. /And the story of my striking roots is now lost" (139). The simple yet powerful translation brings forth the poignant predicament of the tribal population of the land: firstly, they are often labeled as a member of the banned outfit of the state, and secondly, the intervention in the cultural, social and literary spaces of their lives (as the age old belief goes) by the Bengali community has resulted in an unwanted change in as well as a loss of the old tribal rituals and traditions. In his poem "Identity", Kishore Murasingh portrays the morbid and bleak state of the identity of the natives: "Contemporaries call me; /'Hey mama.' /Teacher calls me, /'Hello extremist'. /To the police, /I am a terrorist. /To the leader, /I am a man from the backward class. /To a ration dealer, /I am a BPL card holder. /To somebody else, /'Hey pahariya'. /To some others, /separatist. /There may be innumerable identities. /Sometimes I wonder, /is it not possible for me to be known /as a relative, a brother, a friend, /or as a human 
being (127). The dilemma of a troubled existence due to the conflict within and outside one's entity finds expression in the following lines by the same poet: "I am a living fossil, /I am held captive in a stony darkness" (123). Poet Bikash Roy Debbarma's “Text Message" shocks us with the casual yet serious tone of presenting the problems of insurgency in the land, where taking up arms had once become a house hold way of protecting one's own culture and identity: "How long can we tolerate, /time's moving out of hands. /Take up arms/...Move... (66). The feelings of burning rage and anguish of a tribal youth, probably trying to come to terms with the changes around him and the pressure of the conflict within himself, or simply put, the ethnic conflicts between the tribals and the non-tribals of the state, the bloodshed etc. are evident in the lines of poet Sudhanya Tripura: "Again and again /I speak of love. /I converse with men /in the language of the mind. /Yet, why do men /speak the language of bloodshed? /Why do they desire to speak/ in the language of bloodshed? (90)

Although all the poets included in this volume of translation have their own unique styles of composing verses, yet there is a common thread that binds all their poetry, the thread being the native imagery employed in the poems and their love of the land. The indigenous imagery of the burnt 'Joom', 'the Tongghor', 'the Chongpreng', 'the Nuyai bird', 'the chatak', 'the sharinda' etc. appear as recurrent themes or leitmotifs throughout the volume: "My path leads to the Chethuang forest, /leads to the tongghar in the orchard; /all around my path is Longmaku Shampari /and Longtorai, Shakantan, Jompui, Atharamura...(87). These images are not only an integral part of the tribal life, but also serve as witnesses to the perennial despair and anxiety suffered by the tribal population of the state as Sudhyana Tripura writes: "Someone has taken away the joom crop /Now in the vacant joom hill, /My weeping heart /Stands spellbound (95).

Since an attempt to provide an exact equivalent to the original (native) word might have given birth to an ambiguity in meaning or a sense of loss of cultural sensibility, therefore, the translator has judiciously and deliberately chosen to retain many Kokborok words in his translations of the original texts, such as the ones cited in the previous paragraphs and stanzas, so that these culturesymbols or culture-codes are well understood by the reader who is supposedly an alien or an outsider to the culture of the language being translated. But at the same time, since it is also impossible for the translator to completely negate his own identity and voice in any process of translation (Gupta 2009, 110), therefore it seems that throughout this volume, the translator has tried to create a world of his own perspectives of ethnic clashes, cultural confusions and loss of identity of the tribes of the land, based on his understanding of the tribal culture \& society without interrupting the originality of the 'fragrant' verses.

Although Gupta mentions in the foreword that while translating Kokborok poetry, he had felt that "there is a lack of authentic female voices in this genre", the reader does not quite agree to this view of his. It is true that there are not many female poets in the state who write in Kokborok, but the poetry of Shefali Debbarma and Dipali Debbarma, two prominent names in the genre of Kokborok poetry of Tripura whose works feature in this anthology, voice their expressions of agony, love, loss of the past etc. as authentically as their male counterparts have done. As a matter of fact, the inclusion of two new female poets Kamalia Debbarma and Sabita Debbarma definitely gives a boost to the women writing scene in Kokborok literature of the state. The mythical Nuyai bird comes to life in the words of Dipali Debbarma: "O Nuyai bird, fly back /Over my house again. /You are a living memory /In our fairy tales. /Ruffle your strong winds, /Unfurl your colorful plumes; /beholding you, I shall compose a poem (103). Her reminiscences of a golden past, replete with memories of the family members, the changing seasons, the night sky, the 'chongpreng' and the 'sharinda' etc. in the poem "Who Shall wake us up", faithfully tell a painful tale of the 
nostalgia and loss she is made to live with. The lines perhaps instantly remind us of Kamala Das' "Evening at the Old Nalapat House": "The strains of that melody still linger in my heart. /With cobwebs of my grandpa's memory in a corner of the room/hangs the sharinda, its strings raptured. /I ask myself, "Stringing it again, / who shall evoke the lost tune?" (104).

Shefali Debbarma's poem "Lamination" records the painful sentiments of the tribal folks of the state who are known mostly by the Schedule Tribe cards that they carry. The laminated caste certificate serves not only as a proof of their identity on the land but also seems to constantly remind the cardholder that he/she belongs to a less sophisticated-more barbaric group or civilization. These native jhumias or hill people have always been pushed to the margins as well as discriminated against by the supposedly superior groups of the place. Just as the Brahmin who could not move beyond the 'caste-mark' on his forehead in Kolatkar's "The Bus", Debbarma seems to be suggesting that the non-tribal people of the state possess a prejudice against the natives of the land since the latter belong to the Schedule Tribe category:

Today, after almost a century

the risa and pachchra have been torn to shreds

and diligent termites have fed on the khutruk;

only the S.T. card shines bright within the lamination. (116)

When one re-reads an enlarged and extended version of a book that one had reviewed some years ago, it obviously gives one an opportunity to look at things from new perspectives that probably could not be located in the maiden version. This review, therefore, may be seen as an act of rediscovering of or making up for things left unsaid in the first edition, which certainly calls for a comparative analysis of the two editions. Some important observations in this regard are, firstly, apart from the twelve poets featured in the first edition, this volume includes the poetry of seven new poets. These poets are Kunjabihari Debbarma, Kamalia Debbarma, Sunil Debbarma, Utpal Debbarma, Snehamoy Roy Choudhury, Lakkhidhan Murasingh and Sabita Debbarma. Secondly, this edition includes improvised versions of some (old) poems that were featured in the first volume. Third, the use of a smaller (perhaps better) font size that suits the 'modern' eye has changed the overall appeal of the book in a positive way. Fourth, the cover design of the maiden edition flaunting a dark background with a tree in the middle, perhaps symbolic of the despair and hopelessness of the tribes as well as their affinity and rootedness to the their soil, has been replaced with the design of Tripuri pachhra (a traditional attire in red and white stripes). The use of this motif may be seen as an attempt to restore the lost tribal ethos back to the roots. Last but not the least, the final product, a unique and authentic volume of translation that leaves one amazed at the richness of the Kokborok culture, society \& literature, is worth keeping on one's bookshelves.

\section{References}

Gupta, A. (2009) "Translation as an Act of Ventriloquism: The Author-Translator Hegemony in English Translations of Kokborok Poetry." Translation Today 6.1: pp 107-112. Print.

Misra, T. (2011) ed. The Oxford Anthology of Writings from North-East India: Poetry and Essays. New Delhi: Oxford University Press. Print. 
350 | The Fragrant Joom revisited: A translation of Kokborok poetry in English by Ashes Gupta

Ngangom, R.S., and Nongkynrih, K.S. (2009) eds. Dancing Earth: An Anthology of Poetry from North-East India. New Delhi: Penguin Books. Print.

Nongkynrih, K.S., and Ngangom, R.S. (2003) eds. Anthology of Contemporary Poetry from the North-East. Shillong: North Eastern Hill University. Print.

Singha, S. (2016) "Eco-critical Concerns in Kokborok Poetry from Tripura: A Reading of Select Texts in English Translation.” Muse India Archives. Issue 66, March-April 2016. Retrieved on 10 June 2016. http://www.museindia.com/viewarchive.asp? $\mathrm{myr}=2016 \&$ issid $=66$ 